\title{
Acetylation in Mitochondria Dynamics and Neurodegeneration
}

\author{
Jaylyn Waddell ${ }^{1}$, Aditi Banerjee ${ }^{1}$ and Tibor Kristian ${ }^{2,3, *}$ \\ 1 Department of Pediatrics, University of Maryland School of Medicine, Baltimore, MD 21201, USA; \\ JWaddell@som.umaryland.edu (J.W.); aditi.banerjee@som.umaryland.edu (A.B.) \\ 2 Veterans Affairs Maryland Health Center System, 10 North Greene Street, Baltimore, MD 21201, USA \\ 3 Department of Anesthesiology and the Center for Shock, Trauma, and Anesthesiology Research (S.T.A.R.), \\ University of Maryland School of Medicine, Baltimore, MD 21201, USA \\ * Correspondence: tkristian@som.umaryland.edu; Tel.: +1-410-706-3418
}

Citation: Waddell, J.; Banerjee, A.;

Kristian, T. Acetylation in

Mitochondria Dynamics and

Neurodegeneration. Cells 2021, 10, 3031. https://doi.org/10.3390/ cells10113031

Academic Editors: Paolo Bernardi, Luca Scorrano and Gerardo Z. Lederkremer

Received: 27 September 2021 Accepted: 3 November 2021 Published: 5 November 2021

Publisher's Note: MDPI stays neutral with regard to jurisdictional claims in published maps and institutional affiliations.

Copyright: (c) 2021 by the authors. Licensee MDPI, Basel, Switzerland. This article is an open access article distributed under the terms and conditions of the Creative Commons Attribution (CC BY) license (https:/ / creativecommons.org/licenses/by/ $4.0 /)$.

\begin{abstract}
Mitochondria are a unique intracellular organelle due to their evolutionary origin and multifunctional role in overall cellular physiology and pathophysiology. To meet the specific spatial metabolic demands within the cell, mitochondria are actively moving, dividing, or fusing. This process of mitochondrial dynamics is fine-tuned by a specific group of proteins and their complex post-translational modifications. In this review, we discuss the mitochondrial dynamics regulatory enzymes, their adaptor proteins, and the effect of acetylation on the activity of fusion and fission machinery as a ubiquitous response to metabolic stresses. Further, we discuss the role of intracellular cytoskeleton structures and their post-translational modifications in the modulation of mitochondrial fusion and fission. Finally, we review the role of mitochondrial dynamics dysregulation in the pathophysiology of acute brain injury and the treatment strategies based on modulation of $\mathrm{NAD}^{+}$-dependent deacetylation.
\end{abstract}

Keywords: mitochondria; dynamics; tubulin; acetylation

\section{Introduction}

A mitochondrion is an intracellular organelle that represents an evolutionary product of endosymbiosis, which occurred by fusion of an anaerobic bacterial cell and a proteobacterium possessing a respiratory apparatus with elements of the respiratory chain, the tricarboxylic acid cycle (TCA), and oxidative phosphorylation [1-6]. In this symbiosis, the mitochondrion provided the host cell with aerobically produced energy, while the host cell synthesized metabolites required for the mitochondrial respiration. Due to the endosymbiotic relation, the pro-eucaryotic cells had an energetic and therefore evolutional advantage to survive under the conditions of gradually increasing oxygen concentration in the atmosphere [1-6].

The uniqueness of mitochondria is not only in their evolutionary origin but also in their complex functional diversity. Although these organelles are mainly associated with cellular bioenergetic metabolism, they also play an essential role in the cellular metabolism of macromolecules including lipids, protein, DNA, and RNA. Furthermore, mitochondria play a significant role in the regulation of the cellular response to oxidative stress, and changes in metabolic demands ([7], for review see [8]). Finally, mitochondria have a critical role in regulating cellular calcium homeostasis [9-14]. In contrast to other organelles, mitochondria cannot be formed de novo and have to be generated from preexisting organelles and mitochondrial growth [15]. To efficiently perform their function and successfully assist the cells in managing metabolic challenges associated with changing environment or stress conditions, mitochondria possess features of a dynamic organelle; thus, they can move and go through cycles of fission and fusion [16-22]. These features give the mitochondria the ability to deliver ATP directly where spatially within a cell energy is most required. This is particularly essential for brain cells with complex morphology and an abundant number of processes. Furthermore, the fission of mitochondria ensures a 
proper inheritance and distribution of mitochondria to sister cells during division, and by fragmenting the mitochondria into smaller organelles, the fragments containing damaged structures or malfunctioning proteins can be efficiently removed by mitophagy $[23,24]$.

There are dedicated proteins that are responsible for the fission and fusion of mitochondria. The fission is orchestrated by membrane-associated adaptors and modulated by organellar and cytoskeletal interaction. The activity of proteins that control the mitochondrial dynamics is modulated by post-translational modifications. One of the ubiquitous modifications that is mainly affected by changes in cell bioenergetic metabolism is acetylation. In this review, we discuss the effect of acetylation of fusion/fission proteins, and cytoskeletal proteins involved in mitochondrial dynamics.

\section{Mitochondrial Fission Controlling Machinery}

Proteins controlling mitochondrial fission and fusion interact with the outer and inner mitochondrial membrane in a process that leads either to the division of the organelle into separate individual mitochondria or leads to combining of two organelles into one larger mitochondrion. The executioner of mitochondrial fission is the GTPase of the dynamin superfamily of proteins, known as dynamin-related protein (Drp1). Drp1 requires adaptor proteins to secure the interaction with the mitochondrial outer membrane. Mitochondrial fission 1 (Fis1), mitochondrial fission factor (Mff), and mitochondrial dynamics protein 49/51 (MiD49/51) were identified as adaptor proteins that interact with Drp1 [25,26]. Fis1 has also been implicated as a protein involved in mitophagy, a process that removes dysfunctional mitochondrial organelles $[27,28]$. However, mitophagy is preceded by mitochondrial fragmentation generating several smaller organelles that can be fused with autophagosomes. Mitochondria that are dysfunctional lose their membrane potential and that is followed by ubiquitination of outer membrane proteins by ubiquitin ligase Parkin or MARCH5 leading to initiation of mitophagy $[29,30]$. Mff is a tail-anchored protein that integrates into the mitochondrial outer membrane and also the peroxisomal membrane [31,32]. MiD49 and MiD51 have N-terminal transmembrane anchors for specific interaction with mitochondrial membrane [33]. Each adaptor can independently recruit Drp1 into the outer mitochondrial membrane and their loss results in dysfunctional mitochondrial fission [34-37]. By generating smaller organelles, this process enables mitochondria to move more efficiently within the cell and deliver ATP where it is most needed. Finally, during cell division, mitochondrial fission ensures an equal distribution of mitochondrial mass into daughter cells [24,38].

\section{Proteins Regulating the Fusion Process}

Due to extensive fission, the mitochondrial organelles can reach a submicron size that significantly limits their ability to carry out the bioenergetic functions due to severely reduced availability of essential enzymes and metabolites [39]. To prevent the collapse of cellular bioenergetic metabolism due to over-fragmentation of mitochondrial organelles, there is an opposing fusion process that combines individual organelle content [40]. Thus, the fusion is required for remixing of small organelle content to ensure a sufficient level of enzymes, intermediate metabolites, and number of mitochondrial DNA copies for sustainable and efficient organelle functioning [41]. During the fusion process, two events occur. First, the outer membrane of the two neighboring mitochondria fuse, followed by fusion of their inner membranes. The outcome is a transfer of matrix content through the exchange of mtDNA, proteins, lipids, and metabolites between the newly fused organelles [25,42]. The fusion process is carried out and controlled by three GTPases. Mitofusins 1 and 2 (Mfs1, Mfs2) that are responsible for outer mitochondrial membrane (OMM) fusion, and optic atrophy 1 protein (OPA1), which regulates the conformational changes of the inner mitochondrial membrane (IMM) [43]. Mitofusins are directly involved in the docking and fusion of OMM. The docking activity relies on their ability to self-assemble into oligomers [44]. It has been shown that only deletion of both mitofusins isoforms completely inhibits OMM fusion [45]. However, Mfn1 knockout leads to increased mitochondrial fragmentation, 
while Mfn2 knockout leads to mitochondrial swelling, resulting in a spherical shape [45]. This suggests that Mfn1 and Mfn2 have different roles in the fusion process. Mfn2 is also involved in axonal transport of mitochondria via interaction with Miro protein, an adaptor required for mitochondrial transport along the neuronal axons [46]. Furthermore, both mitochondrial division and fusion occur at contact sites of endoplasmic reticulum (ER) and mitochondria, and it was suggested that Mfn2 mediates ER-mitochondria tethering [47,48]. The mitofusins also interact with adaptor proteins on the OMM to carry out the fusion process. Misato (MSTO1) has been reported to be involved in OMM fusion [49], and it was suggested that this adaptor protein can support mitochondrial fusion through initiation of the fusion process $[50,51]$.

Inner mitochondrial membrane fusion is controlled by dynamin-like GTPase OPA1. Opa1 activity is directly regulated by proteolytic cleavage. Once this protein is imported into mitochondria, the mitochondrial processing peptidase cleaves the mitochondria targeting sequence, producing the long isoforms (L-OPA1) [52-55]. OPA1 controls both mitochondrial IMM fusion and cristae morphology [52,54,56,57]. L-OPA1 isoforms can be further proteolytically cleaved into short forms (S-OPA1) soluble in the intermembrane space. There are two proteolytic cleavage sites where the OPA1 protein is cleaved by mitochondrial metallo-endopeptidases OMA1, and ATP-dependent zinc metalloprotease YME1L [58-60]. Both S-OPA1 and L-OPA1 are present in mitochondria under normal, physiologic conditions; however, the pro-fusion activity of OPA1 is mostly associated with the L-OPA1 isoform. OMA1 is activated upon stress insults, resulting in degradation of L-OPA1 and leading to mitochondrial fragmentation [61-63]. The role of the two OPA1 versions in the fusion process is not clear. Initially, it was reported that both L-, and S-OPA1 are required for the fusion [64]. However, other reports suggested that only the L-OPA1 is the profusion form $[52,59,65]$. As mentioned above, the S-OPA1 is produced after proteolytic cleavage of L-OPA1 activated by stress or pathologic conditions. The increase in the soluble S-OPA1 levels was observed following global cerebral ischemia $[39,66]$ and neonatal hypoxic-ischemic brain injury [67]. This was accompanied by increased fragmentation of mitochondria in brain cells. Similarly, reduced levels of L-OPA1 were associated with cessation of mitochondrial fusion and mitochondrial cristae dilation after excitatory insult [68]. Overexpressing OPA1 reversed the changes in mitochondrial morphology and increased neuronal survival after excitotoxic insult [68]. Generation of the short OPA1 isoform along with fragmentation of mitochondria is favored at low membrane potential and low ATP levels $[52,64,69,70]$. Thus, conversion of OPA1 to the short isoform inhibits the fusion machinery of dysfunctional organelles and prevents the fusion of defective organelles with the functioning mitochondrial network, contributing to quality control $[60,61]$.

\section{Tight Regulation of Fission and Fusion Proteins Activity by Post-Translational Modifications}

The interaction of the adaptor proteins with Drp1 is fine-tuned by post-translational modifications including SUMOylation, ubiquitination, phosphorylation, S-nitrosylation, O-linked-N-acetyl-glucosamine glycosylation, and acetylation (for review see [24]). Phosphorylation was identified as the major post-translational modification that regulates Drp1. There are two serine residues that are phosphorylated in Drp1. Phosphorylation of Ser616 activates the Drp1 binding to the adaptor proteins in the outer mitochondrial membrane and leads to increased mitochondrial fission, whereas phosphorylation of Ser637 prevents the Drp1 activation [24,71]. Fission-related adaptors are also subject to post-translational modifications. The March5 ubiquitin ligase regulates the levels of MiD49, and MFF is phosphorylated via AMP-activated protein kinase (AMPK) under stress conditions [72,73]. Another ubiquitous post-translational modification that modulates the activity of fusion and fission protein is lysine acetylation.

\subsection{Role of Acetylation in Control of Mitochondrial Dynamics}

Acetylation of histone and non-histone proteins is a post-translational modification that has been known for decades [74-76]. During acetylation, the acetyl group donated 
by acetyl-CoA (AcCoA) is transferred to a lysine residue of the target protein by histone acetyltransferases (HATs). This process is highly reversible by activity of histone deacetylases (HDACs). HDACs can be broadly divided into four classes. Class I is represented by HDACs (1,2,3 and 8), in class II HDACs 4,5,6,7,9, and 10 is identified, class III HDACs are also called sirtuins (SIRT1-SIRT7), and finally, HDAC 11 represents class IV [77].

Sirtuins require $\mathrm{NAD}^{+}$for their activity and modulate protein signaling and function by transferring the acetyl group from the lysine of acetylated protein to the ADP-ribose moiety of $\mathrm{NAD}^{+}$. During this process nicotinamide is cleaved from $\mathrm{NAD}^{+}$and $O$-acetylADP-ribose is generated [78]. SIRT1, SIRT6, and SIRT7 are localized in the nucleus [79], SIRT2 is considered to be a cytosolic protein [80], and SIRT3-5 were identified as mitochondrial proteins [81-84]. However, only SIRT3 plays a key role in deacetylation of mitochondrial proteins $[81,82]$. SIRT4 shows ADP-ribosyl transferase activity $[83,85]$ and SIRT5 acts as desuccinylase [86,87] (see Table 1 ).

Table 1. NAD ${ }^{+}$-dependent deacetylases Sirtuins.

\begin{tabular}{cccc}
\hline Sirtuin & Localization & Activity & Reference \\
\hline SIRT1 & Cytosol, nucleus & deacetylase & {$[88]$} \\
SIRT2 & Cytosol & deacetylase & {$[89]$} \\
SIRT3 & Mitochondria & deacetylase & {$[90]$} \\
SIRT4 & Mitochondria & ADP-ribosyl transferase & {$[85]$} \\
SIRT5 & Mitochondria & desuccinylase & {$[91]$} \\
SIRT6 & nucleus & ADP-ribosyl transferase & {$[92]$} \\
SIRT7 & nucleus & deacetylase & [93]
\end{tabular}

Histone acetyltransferases (HATs) are generally categorized as nucleic or cytoplasmic HATs $[94,95]$. Mitochondrial proteins are acetylated by mitochondria-specific acetyltransferase, general control amino acid synthesis 5-like 1 (GCN5L1) [96]. GCN5L1 is a non-transmembrane protein located within mitochondria [96].

Recently, it was reported that Drp1 can also be acetylated at lysine 642 (K642) [97]. The increased acetylation of Drp1 in heart mitochondria was observed under conditions of a high-fat diet that resulted in accumulation of AcCoA and increased total protein acetylation including Drp1. The Drp1 acetylation was coupled with phosphorylation of Drp1 at S616 and its translocation to mitochondria (Figure 1). High-fat diet also significantly decreased total intracellular $\mathrm{NAD}^{+}$content. Restoration of $\mathrm{NAD}^{+}$levels prevented the Drp1 hyperacetylation and blocked the Drp1 phosphorylation at S616, suggesting that $\mathrm{NAD}^{+}$- mediated acetylation regulates Drp1 protein fission activity. Thus, Drp1 acetylation at K642 was required for increased Drp1 phosphorylation at S616, which promoted its mitochondrial translocation and fission activity [98]. Although in this work the deacetylase that was responsible for removing the acetyl group Drp1 was not identified, the finding that this process was $\mathrm{NAD}^{+}$dependent suggests an involvement of cytosolic $\mathrm{NAD}^{+}$-dependent deacetylase SIRT2.

The fission process is controlled not only by the Drp1 acetylation but also by the acetylation of adaptor protein Fis1. For example, decreased cellular AcCoA levels due to increased lipid generation by acetyl-CoA carboxylase alpha (ACC1) leads to enhanced mitochondrial fission [99]. This is because ACC1 activation reduces cellular AcCoA level, thereby inhibiting Fis1 protein acetylation, which blocks Fis1 polyubiquitination and subsequent proteasome degradation [99]. Thus, Fis1 effect on mitochondrial dynamics is fine-tuned by the interplay between acetylation and ubiquitination of these proteins.

Under pathologic conditions, Opa1 is also hyperacetylated. This reduces its GTPase activity, thus inhibiting the fusion process, increasing mitochondrial fragmentation [100]. Once Opa1 is deacetylated by SIRT3, the fusion activity of OPA1 is restored [100]. Similarly, acetylation status of Mfn1 also affects the fusion process. Under fasting conditions, Mfn1 is deacetylated by HDAC6 leading to mitochondrial hyperfusion [101] due to increased fusion activity of its deacetylated form. This process is linked to interaction of Mfn1 with MARCH5 causing subsequent Mfn1 ubiquitination. Thus, these data imply that the 
increased ubiquitination of Mfn1 is dependent on its acetylation status [102], and suggests a possibility that once the fusion process is carried out, Mfn1 is destined for degradation by the ubiquitin-proteasomal system (Figure 2).

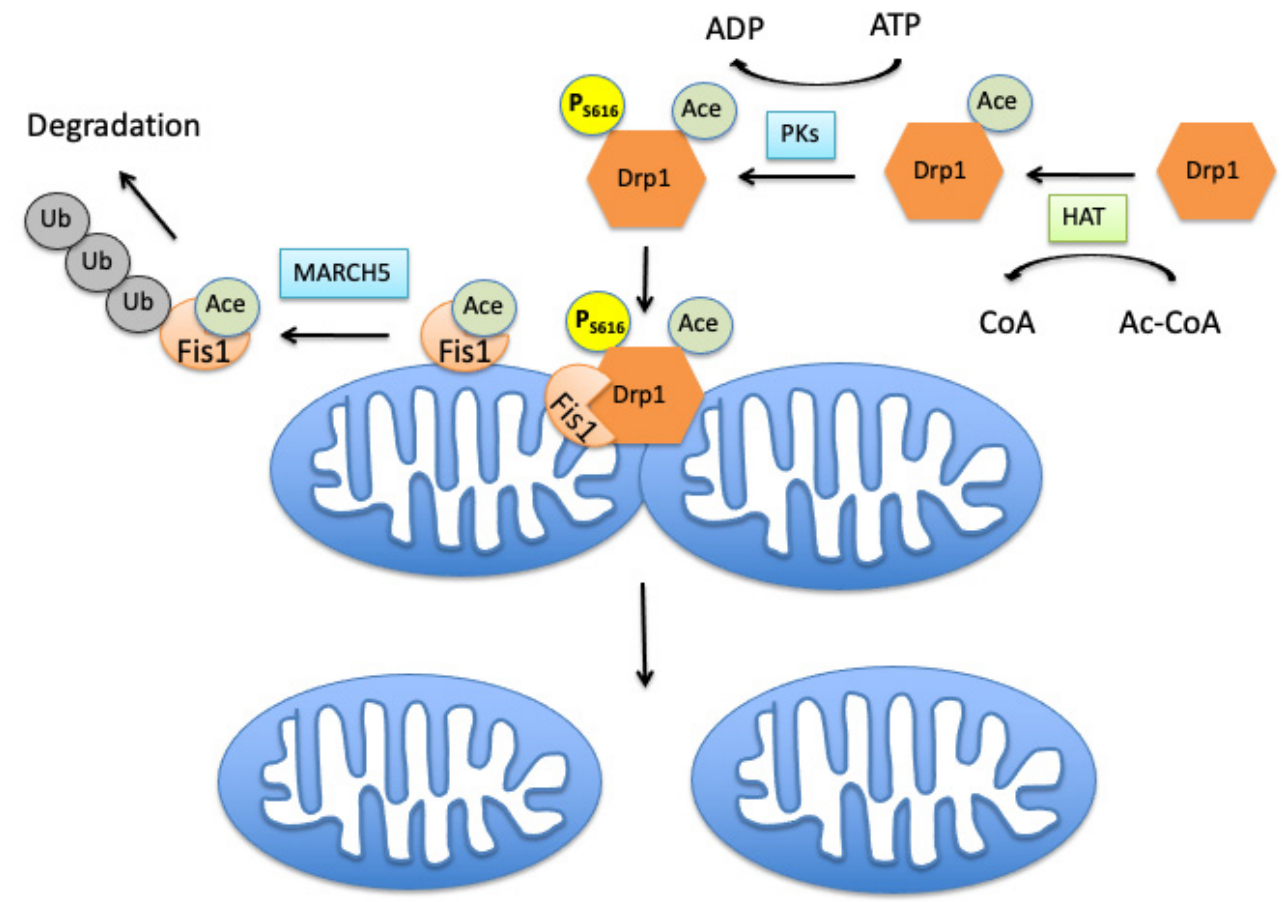

Figure 1. Acetylation of mitochondrial fission proteins. The acetylation of Drp1, a fission driving protein, by cytosolic histone acetyltransferase (HAT) enables its phosphorylation at serin 616 residue by protein kinases (PKs) and its translocation to mitochondria by binding to the Fis1 adaptor located in the outer mitochondrial membrane (OMM), thus promoting mitochondrial fission. Increased acetylation of Fis1 is linked to its ubiquitination by ubiquitin ligase MARCH5 and proteolytic degradation. HAT transfers the acetyl group from acetyl-CoA (Ac-CoA) to the target protein generating acetylated protein and coenzyme A (CoA).

\subsection{Effects of Mitochondrial Protein Acetylation on Free Radical-Induced Fission and Fusion Dynamics}

The fission activity of Drp1 is also stimulated by modifications induced via the interaction of the Drp1 protein with free radicals, particularly nitric oxide (NO). NO belongs to a family of reactive nitrogen species and signals primarily through the formation of S-nitrosothiols, representing S-nitrosylation [103]. Furthermore, NO reacts readily with superoxide generating highly reactive peroxynitrite, which can nitrate tyrosine residues to form nitrotyrosine [103]. The cysteine residue (Cys644) of Drp1 can be S-nitrosylated by nitric oxide (NO) leading to increased Drp1-induced fission [25].

One of the adverse side effects of mitochondrial respiration is the production of free radicals, mainly by the respiratory chain enzymes [104,105]. However, free radicals also serve as signaling molecules regulating several biochemical processes [106]. To maintain the ROS levels within physiological range mitochondria and cells possess enzymatic machinery that eliminates the excess of free radicals [104,107-109]. These antioxidant mechanisms in mitochondria include the matrix manganese superoxide dismutase (MnSOD), glutathione (GSH), glutathione reductase (GR), glutathione peroxidase (GPX), and the thioredoxin system $[107,108,110,111]$. MnSOD is essential in protection of mitochondria against oxidative stress since it detoxifies superoxide [110]. 


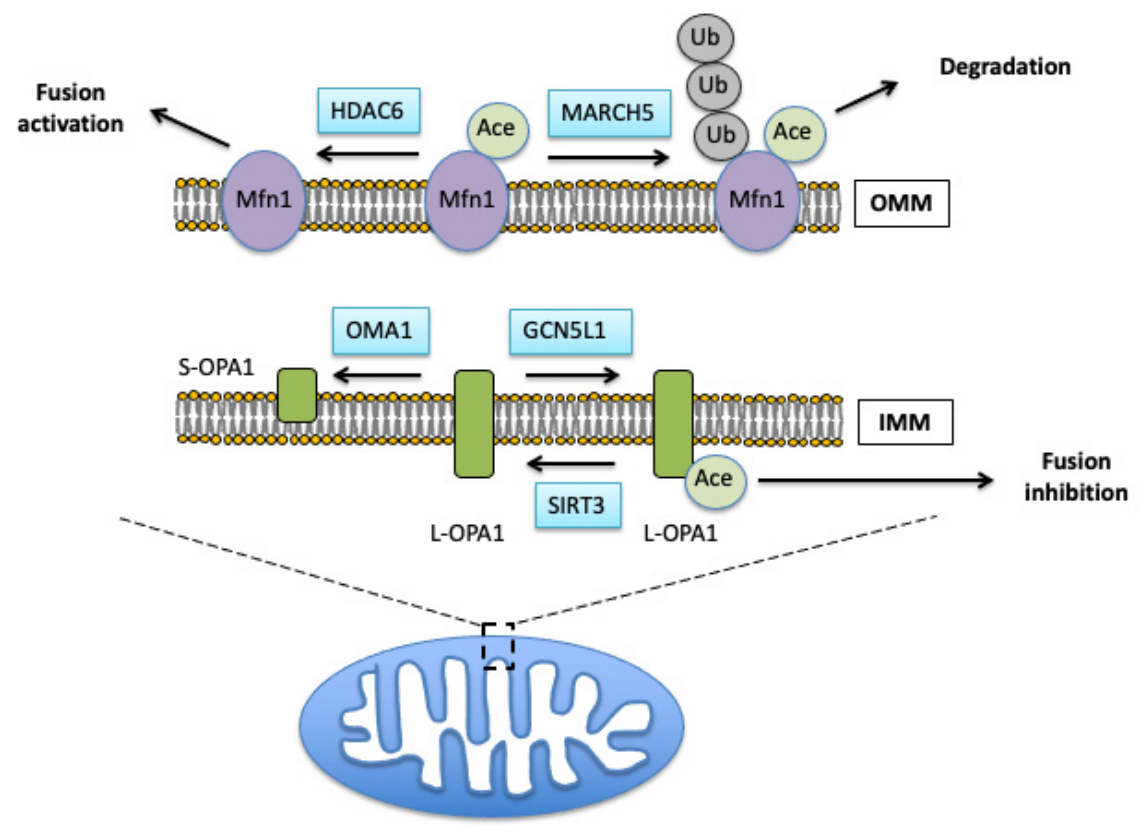

Figure 2. Acetylation of fusion regulating proteins. Acetylation of mitofusion1 (Mfn1) results in ubiquitination of this protein by MARCH5 and its proteasomal removal. Mfn1 is deacetylated by histone deacetylase 6 (HDAC6) leading to increased fusion activity. Hyperacetylation of the inner membrane (IMM) fusion protein OPA1 by mitochondrial acetyl transferase GCN5L1 results in inhibition of its fusion activity. Mitochondrial SIRT3 deacetylates OPA1 which has a profusion effect. OPA1 is cleaved by mitochondrial metallo-proteases OMA1 and YME1L into short isoforms.

Acetylation affects the activity of the MnSOD [112-114]. Hyperacetylation of this enzyme under stress or pathologic conditions results in increased production of superoxide due to acetylation-induced inhibition of MnSOD [115-117]. The increased levels of superoxide facilitate peroxynitrite production and S-nitrosylation of DRP1, resulting in increased mitochondrial fragmentation $[39,116]$. The acetylation of MnSOD is controlled by NADdependent SIRT3 implying that changes in mitochondrial NAD ${ }^{+}$pools can significantly impact superoxide levels and the mitochondrial fission process. Thus, the maintenance of physiological matrix $\mathrm{NAD}^{+}$levels is essential not only for mitochondrial respiratory functions but also impacts mitochondrial dynamics [116]. This notion is supported by data showing that reduced mitochondrial $\mathrm{NAD}^{+}$levels following ischemic insult lead to extensive mitochondrial fission that can be reversed by administration of $\mathrm{NAD}^{+}$precursor nicotinamide mononucleotide (NMN) [116], and that SIRT3 knockout animals show extensively fragmented brain mitochondria when compared to wild type animals [105]. Thus, the NMN treatment prevents the pathologic post-ischemic NAD ${ }^{+}$consumption, inhibits the increase in free radical production leading to recovery of mitochondrial shape and protects against ischemia-induced brain damage [116].

\section{Role of Cellular Cytoskeleton in Mitochondrial Fission/Fusion Dynamics}

To support the diverse functions of mitochondria within the cell, particularly in ones with complex morphology represented by neurons and glia, the mitochondria move along microtubules (MT) aided by motor proteins $[118,119]$. Actin microfilaments (MFs) also play a role in mitochondrial transport [120-122]. In cells, which lack MTs but retain essentially normal levels of MFs, mitochondria continue to move bidirectionally but the average mitochondrial velocity is reduced for both directions of movement [120]. However, in axons disassembling microtubules leads to complete elimination of mitochondrial motility [123]. In cells, which retain microtubules but are lacking microfilaments, the average mitochondrial velocity is increased [120]. Thus, mitochondrial transport can occur along both microtubules and microfilaments, but with different velocities. 
Microtubules are cylindrical polymers composed of $\alpha$ - and $\beta$-tubulin heterodimers [124]. Their functional diversity can be regulated by post-translational modifications (PTMs) $[125,126]$. The structures of microtubules are stabilized by binding other proteins called microtubuleassociated proteins (MAPs).

Interaction of mitochondria with microtubules and their movement depends on MAPs and their post-translational modifications [127]. MAPs can be divided into microtubule stabilizers and destabilizers, and molecular motors that are responsible for mitochondria movement [126,127]. Motor proteins include kinesins that drive anterograde transport and dyneins, which typically drive retrograde mitochondrial movement but also can be involved in bidirectional transport [118,128].

The major post-translational modifications that regulate microtubule cytoskeleton include detyrosination, $\Delta 2$-tubulin generation, glutamylation, glycylation, and acetylation [126]. Detyrosination denotes a reversible removal of C-terminal tyrosine and the detyrosinated tubulin can then be further converted into $\Delta 2$-tubulin [129]. This represents very stable MTs as a final stage of functional differentiation [130].

Glutamylation and glycylation are also a modification of the C-terminal tails of tubulins and provide a mechanism for fine-tuning the interactions between microtubules and their binding partners including motor proteins [131,132].

\subsection{Actin Cytoskeleton Acetylation and Mitochondrial Fission}

The fission of mitochondrial organelles is preferentially observed at the sites where there is a close contact of mitochondria with endoplasmic reticulum (ER), suggesting that the ER plays a significant role in mitochondrial division [133]. The interaction of ER and mitochondria during the fission process is mediated by actin polymerization and recruitment of Drp1. The actin polymerization is carried out through ER-bound actin assembly factor inverted formin 2 (INF2) [134] and mitochondrial Spire1C [135]. The polymerized actin promotes Drp1 recruitment to the mitochondrial surface. Actin polymerization is stimulated by mitochondrial calcium uptake from ER, associated with increased activity of mitochondrial respiratory chain [136] and is affected by actin-depolymerizing protein cofilin1 that acts as a negative regulator of mitochondrial Drp1 activity [137]. Actins contain several lysine residues that can be acetylated [138]. Complex of acetylated actin with cyclase-associated protein (CAP) inhibits INF2, and this inhibition can be released by HDAC6 [139]. Thus, actin acetylation affects its polymerization at ER-mitochondria contact sites and downstream can modulate the mitochondrial fission process.

\subsection{Mitochondrial Movement and Tubulin Acetylation}

Acetylation of $\alpha$-tubulin at lysin 40 was reported as a specific post-translational modification that enhances recruitment of kinesin-1 and dynein/dynactin motor complexes to microtubules that results in increased anterograde and retrograde transport $[140,141]$. However, the mechanisms of this interaction are not clear since lysine 40 is localized on the inside of the microtubule polymer [142], whereas most interactions between microtubules and their associated proteins take place along the microtubules outer surface. It was suggested that the acetylation of the lysine 40 residue of $\alpha$-tubulin modulates microtubule conformation by triggering subtle changes in the way tubulins interacts with each other $[143,144]$ and in this way, stimulate the interaction with motor proteins $[140,141,145]$.

Tubulin acetylation level is a result of a balance between the activity of the cytoplasmic deacetylases HDAC6 and SIRT2 and several acetyltransferases [146]. Alpha-tubulin acetyltransferase $1 \alpha \mathrm{TAT} 1 / \mathrm{MEC}-17$ was reported as a major acetyltransferase targeting tubulin [147-149]. It was shown that MEC-17 knockdown dramatically reduces tubulin acetylation under both basal or various stress-induced conditions, and it is required for stress-induced MT hyperacetylation [150]. HDAC6 and SIRT2 were reported to co-localize along the microtubule network and coimmunoprecipitate. Furthermore, tubulin hyperacetylation was observed after silencing of HDAC6 or SIRT2 alone suggesting that these deacetylases act interdependently in a protein complex [151]. In the brain, however, SIRT2 
shows abundant expression, particularly during adult age [152], and HDAC6-deficient mice do not show increased tubulin acetylation in brain tissue when compared to wild-type animals [153]. However, another study did find increased $\alpha$-tubulin acetylation in the brain of HDAC6 knockout animals [154]. Furthermore, there are conflicting results in the literature regarding the cell-type-specific distribution of HDAC6. High expression levels of HDAC6 were shown predominantly in Purkinje cells [155] (however, see [154]) and in neurons of dorsal and median raphe nuclei [156]. HDAC6 is expressed only in very few hippocampal and cortical neurons [156]. Nevertheless, HDAC6 inhibition promoted both retrograde and anterograde mitochondrial movement in hippocampal or motor neurons together with increased tubulin acetylation $[157,158]$. These conflicting results might reflect the age-dependent differences in HDAC6 expression levels in cell culture since the HDAC6 distribution in brain was examined using brain tissue sections from adult animals and the effect of HDAC6 inhibitors on mitochondrial movement was observed in primary neuronal tissue culture. Furthermore, downregulation of HDAC6 causes a reduction in the net activity of mitochondrial enzymes, including respiratory complex II and citrate synthase [159]. Acetylation of $\alpha$-tubulin also modulates mitochondrial length by affecting the organelles transport activity and by modulating the interaction of mitofusin 2 with motor proteins [46]. Kim et al. [160] reported that motile mitochondria are longer than stationary ones, suggesting that the change in mitochondrial length is coupled with dynamics of mitochondrial transport. A list of mitochondrial dynamics control proteins that activity is modulated by acetylation is in Table 2 .

These reports suggest that although mitochondrial dynamics are predominantly regulated by the fission and fusion proteins and their post-translational modifications, during the last step of the fission process the individual organelles need to physically move from each other, or to initiate fusion they need to gain close contact. This is ensured by the organelle's movement. Thus, the transport of mitochondria along the cytoskeleton composed of microtubules and microfilaments represents an additional control step that is also fine-tuned by post-translational modifications of the cytoskeleton and motor proteins. However, as we mentioned above, the mitochondrial fission sites are found at ER and also at multiple organelles, including lysosomes and trans-Golgi network (TNG) vesicles $[161,162]$. Examination of the interaction between mitochondrial fission and the TGN vesicles suggests that these vesicles drive the last step of mitochondrial division [163]. Another possibility is that the smaller organelles can locally change their position driven by thermal energy, without the involvement of cellular transport machinery, to facilitate fission or fusion. However, this process is random, lacking any control or modulation by changes in intracellular metabolic conditions. Furthermore, data showing striking absence of any mitochondrial motility in cells lacking both microtubules and microfilaments suggest that the contribution of this type of movement to overall mitochondrial transport is probably negligible [120]. However, it might facilitate the final separation of vesicles during fission or help to initiate the outer mitochondrial membrane fusion.

Table 2. Fission and fusion proteins modulated by acetylation.

\begin{tabular}{cccc}
\hline Dynamics Protein & Acetylated Lysine & Acetylation & Reference \\
\hline Drp1 & K642 & NAD $^{+}$-dependent & {$[90]$} \\
Fis1 & ND & TSA and Nam 1 & {$[95]$} \\
Mfn1 & ND & SIRT1/SIRT2 & {$[93]$} \\
Mfn2 & ND & SIRT1/SIRT2 & {$[164]$} \\
OPA1 & ND & SIRT3 & {$[92]$} \\
$\alpha$-tubulin & K40 & $\alpha$ TAT1/SIRT2/HDAC6 & {$[134,136]$} \\
actin & K50, K61, K328 & HDAC6 & {$[139]$} \\
\hline
\end{tabular}

1 Acetylation is affected by deacetylases inhibitor trichostatin A (TSA) and nicotinamide (Nam); ND, not determined. 


\section{Pathophysiology of Mitochondrial Dynamics Dysfunction}

Since mitochondrial dynamics are integral to several essential processes in living cells, disturbance in the regulation of these mechanisms is associated with several neurodegenerative diseases or acute brain injury (for review see $[19,146,165]$ ). Excessive mitochondrial fragmentation can lead to a decline in mitochondrial bioenergetic activity, followed by cellular bioenergetic failure and ultimately cell death $[19,24,39,66,166]$. Increased, excessive fragmentation of mitochondria in neurons or astrocytes was reported following ischemic, traumatic or excitotoxic insult [39,66,167-172]. The notion that heavily fragmented mitochondria can lead to cellular pathophysiology and cell death is supported by the observation of differential, hippocampal subregion-specific changes in mitochondrial fission following ischemic insult $[39,116]$. After initial post-ischemic fragmentation, mitochondria in ischemia-resistant CA3 and dentate gyrus neurons can fuse and regain their pre-ischemic shape and length [39]. However, in the vulnerable CA1 neurons that die during reperfusion, mitochondrial fragmentation is not reversed, but progresses generating submicron size organelles [39]. Interestingly, administration of nicotinamide mononucleotide (NMN) following the ischemic insult leads to dramatic neuroprotection [173], and recovery of mitochondrial morphology in CA1 neurons [116].

\section{Role of $\mathrm{NAD}^{+}$in the Regulation of Mitochondrial Dynamics in Acute Brain Injury}

$\mathrm{NMN}$ is an endogenous metabolite that serves as a precursor for $\mathrm{NAD}^{+}$synthesis by nicotinamide mononucleotide adenylyl transferase (Nmnat) enzyme [174]. Mitochondrial $\mathrm{NAD}^{+}$levels in the brain are depleted following ischemic insult, and NMN treatment normalizes the post-ischemic $\mathrm{NAD}^{+}$pools $[116,173]$. The changes in intracellular and mitochondrial $\mathrm{NAD}^{+}$levels can affect the fusion and fission process via post-translational modifications (PTM) of the proteins that control the mitochondrial dynamics (see above). Thus, $\mathrm{NAD}^{+}$can have a direct impact on the acetylation levels of mitochondrial enzymes via modulation of intramitochondrial deacetylase SIRT3 activity. Similarly, changes in cytosolic $\mathrm{NAD}^{+}$levels can affect the Drp1 and microtubules acetylation via NAD ${ }^{+}$-dependent SIRT2 activity $[89,97,155]$. Indirectly, the intramitochondrial $\mathrm{NAD}^{+}$affects the mitochondrial reactive oxygen species (ROS) production, and this way also impacts free radical-dependent post-translational modification of Drp1 $[116,175]$. The reduced mitochondrial NAD ${ }^{+}$levels lead to oxidative stress and activation of mitochondrial fission $[25,103]$. Thus, ischemic insult depletes mitochondrial $\mathrm{NAD}^{+}$pools and consequently increases mitochondrial protein acetylation that contributes to post-ischemic oxidative stress and shifts mitochondrial dynamics towards fission $[116,175]$. The role of mitochondrial SIRT3 activity was confirmed also by using SIRT3 knockout animals that showed hyperacetylation of mitochondrial proteins, higher free radical production, and more fragmented mitochondria when compared to wild type animals [116]. Furthermore, increased acetylation of Drp1 promotes its activity and causes mitochondrial fragmentation [97]. This can be reversed by supplementation of $\mathrm{NAD}^{+}$precursor NMN [97]. These data thus suggest that also cytosolic $\mathrm{NAD}^{+}$levels can alter mitochondrial morphology via acetylation of Drp1 most likely by modulation of SIRT2 activity. Similarly, since microtubules acetylation is one of the factors affecting mitochondrial movement and dynamics, the ischemia-induced reduction in microtubules stability due to decreased microtubules acetylation and reduced expression of MAPs is associated with post-ischemic cell death $[176,177]$. Acetylation effects on mitochondrial interaction with microtubules and related fusion/fission proteins are shown in Figure 3. 


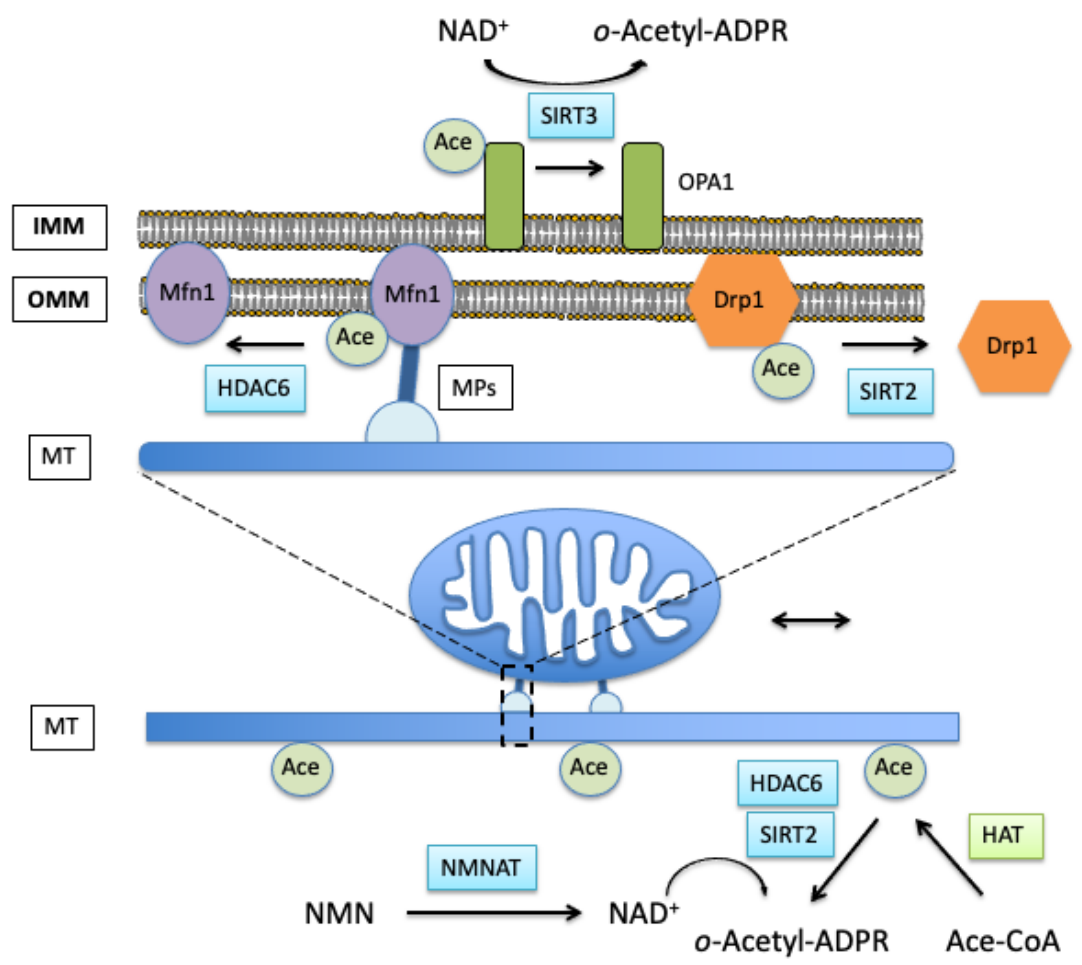

Figure 3. $\mathrm{NAD}^{+}$-dependent effect on acetylation-induced modulation of mitochondrial dynamics. Nicotinamide mononucleotide (NMN) serves as precursor for $\mathrm{NAD}^{+}$syntheses by nicotinamide mononucleotide adenylyl transferase (NMNAT). NAD ${ }^{+}$is a substrate for class III deacetylases (sirtuins) that transfer the acetyl group from acetylated proteins to the ADP-ribose (ADPR) moiety of NAD ${ }^{+}$ forming $o$-acetyl-ADP-ribose (o-Acetyl-ADPR). Increased cytosolic and mitochondrial $\mathrm{NAD}^{+}$levels increase the activity of cytosolic SIRT2, and mitochondrial SIRT3, thus, modulating the acetylation of microtubules (MT) and proteins controlling the mitochondrial fission and fusion processes (Mfn1, Drp1, OPA1). Microtubules and Mfn1 can be also deacetylated by HDAC6. Acetylated Mfn1 can interact with motor proteins (MPs), enabling mitochondrial movement along the microtubules.

\section{Conclusions}

Acetylation is one of the most ubiquitous post-translational modifications that represents a universal mechanism of regulation of enzymes activity including one that controls the mitochondrial dynamics. The balance between fission and fusion is essential for mitochondria to work properly and maintain a healthy functioning cell.

Most studies examining the pathophysiology of mitochondrial dynamics focused on changes in expression levels of fusion and fission proteins or the aberrant changes in their posttranslational modifications. However, the physiological cycles of mitochondrial fission and fusion also depend on mechanisms that involve and control mitochondrial movement. Therefore, when examining treatment strategies, one should also consider targeting the mechanisms involved in mitochondrial movement and its regulation, including proteins associated with the interaction of mitochondria with other intracellular organelles. Thus, the therapeutical approach needs to target several mechanisms to be effective and have a significant impact.

Author Contributions: Conceptualization, writing—original draft preparation, T.K.; writing—review and editing, J.W. and A.B.; funding acquisition, T.K. and J.W. All authors have read and agreed to the published version of the manuscript.

Funding: This research was funded by NIH NINDS R01NS119275 and the Veteran's Affairs Merit Re view Award BX004895 to T.K., and NIH NINDS P01 and HD085928-01A15749 to J.W.

Institutional Review Board Statement: Not applicable. 
Informed Consent Statement: Not applicable.

Data Availability Statement: Not applicable.

Conflicts of Interest: The authors declare no conflict of interest.

\section{References}

1. Gray, M.W.; Burger, G.; Lang, B.F. Mitochondrial evolution. Science 1999, 283, 1476-1481. [CrossRef] [PubMed]

2. Gray, M.W.; Burger, G.; Lang, B.F. The origin and early evolution of mitochondria. Genome Biol. 2001, 2, 1-5. [CrossRef]

3. Gray, M.W. Mitochondrial evolution. Cold Spring Harb. Perspect. Biol. 2012, 4, a011403. [CrossRef] [PubMed]

4. Henze, K.; Martin, W. Evolutionary biology: Essence of mitochondria. Nature 2003, 426, 127-128. [CrossRef] [PubMed]

5. Martin, W.; Hoffmeister, M.; Rotte, C.; Henze, K. An overview of endosymbiotic models for the origins of eukaryotes, their ATP-producing organelles (mitochondria and hydrogenosomes), and their heterotrophic lifestyle. Biol. Chem. 2001, 382, 1521-1539. [CrossRef] [PubMed]

6. Wang, Z.; Wu, M. An integrated phylogenomic approach toward pinpointing the origin of mitochondria. Sci. Rep. 2015, 5, 7949. [CrossRef] [PubMed]

7. Gwangwa, M.V.; Joubert, A.M.; Visagie, M.H. Crosstalk between the Warburg effect, redox regulation and autophagy induction in tumourigenesis. Cell. Mol. Biol. Lett. 2018, 23, 20. [CrossRef] [PubMed]

8. Spinelli, J.B.; Haigis, M.C. The multifaceted contributions of mitochondria to cellular metabolism. Nat. Cell Biol. 2018, 20, 745-754. [CrossRef] [PubMed]

9. Rizzuto, R.; Bernardi, P.; Pozzan, T. Mitochondria as all-round players of the calcium game. J. Physiol. 2000, 529 Pt 1, $37-47$. [CrossRef] [PubMed]

10. Kristian, T.; Siesjo, B.K. Calcium-related damage in ischemia. Life Sci. 1996, 59, 357-367. [CrossRef]

11. Stout, A.K.; Raphael, H.M.; Kanterewicz, B.I.; Klann, E.; Reynolds, I.J. Glutamate-induced neuron death requires mitochondrial calcium uptake. Nat. Neurosci. 1998, 1, 366-373. [CrossRef]

12. Orrenius, S.; Zhivotovsky, B.; Nicotera, P. Regulation of cell death: The calcium-apoptosis link. Nat. Rev. Mol. Cell Biol. 2003, 4, 552-565. [CrossRef] [PubMed]

13. Kristian, T. Metabolic stages, mitochondria and calcium in hypoxic/ischemic brain damage. Cell Calcium 2004, 36, 221-233. [CrossRef] [PubMed]

14. Dubinsky, J.M.; Brustovetsky, N.; Pinelis, V.; Kristal, B.S.; Herman, C.; Li, X. The mitochondrial permeability transition: The brain's point of view. Biochem. Soc. Symp. 1999, 66, 75-84. [PubMed]

15. Jornayvaz, F.R.; Shulman, G.I. Regulation of mitochondrial biogenesis. Essays Biochem. 2010, 47, 69-84. [CrossRef] [PubMed]

16. Kraus, F.; Roy, K.; Pucadyil, T.J.; Ryan, M.T. Function and regulation of the divisome for mitochondrial fission. Nature 2021, 590, 57-66. [CrossRef] [PubMed]

17. Lee, H.; Yoon, Y. Mitochondrial fission and fusion. Biochem. Soc. Trans. 2016, 44, 1725-1735. [CrossRef] [PubMed]

18. Balog, J.; Mehta, S.L.; Vemuganti, R. Mitochondrial fission and fusion in secondary brain damage after CNS insults. J. Cereb. Blood Flow Metab. 2016, 36, 2022-2033. [CrossRef] [PubMed]

19. Westermann, B. Mitochondrial fusion and fission in cell life and death. Nat. Rev. Mol. Cell Biol. 2010, 11, 872-884. [CrossRef] [PubMed]

20. Youle, R.J.; van der Bliek, A.M. Mitochondrial fission, fusion, and stress. Science 2012, 337, 1062-1065. [CrossRef]

21. Pernas, L.; Scorrano, L. Mito-Morphosis: Mitochondrial Fusion, Fission, and Cristae Remodeling as Key Mediators of Cellular Function. Annu. Rev. Physiol. 2016, 78, 505-531. [CrossRef] [PubMed]

22. Cagalinec, M.; Safiulina, D.; Liiv, M.; Liiv, J.; Choubey, V.; Wareski, P.; Veksler, V.; Kaasik, A. Principles of the mitochondrial fusion and fission cycle in neurons. J. Cell Sci. 2013, 126, 2187-2197. [CrossRef]

23. Yaffe, M.P. The machinery of mitochondrial inheritance and behavior. Science 1999, 283, 1493-1497. [CrossRef] [PubMed]

24. Klimova, N.; Long, A.; Kristian, T. Significance of Mitochondrial Protein Post-translational Modifications in Pathophysiology of Brain Injury. Transl. Stroke Res. 2018, 9, 223-237. [CrossRef]

25. Chen, H.; Chan, D.C. Mitochondrial dynamics-Fusion, fission, movement, and mitophagy-In neurodegenerative diseases. Hum. Mol. Genet. 2009, 18, R169-R176. [CrossRef]

26. Anderson, C.A.; Blackstone, C. SUMO wrestling with Drp1 at mitochondria. EMBO J. 2013, 32, 1496-1498. [CrossRef] [PubMed]

27. Shen, Q.; Yamano, K.; Head, B.P.; Kawajiri, S.; Cheung, J.T.; Wang, C.; Cho, J.H.; Hattori, N.; Youle, R.J.; van der Bliek, A.M. Mutations in Fis1 disrupt orderly disposal of defective mitochondria. Mol. Biol. Cell 2014, 25, 145-159. [CrossRef] [PubMed]

28. Rojansky, R.; Cha, M.Y.; Chan, D.C. Elimination of paternal mitochondria in mouse embryos occurs through autophagic degradation dependent on PARKIN and MUL1. Elife 2016, 5, e17896. [CrossRef] [PubMed]

29. Glauser, L.; Sonnay, S.; Stafa, K.; Moore, D.J. Parkin promotes the ubiquitination and degradation of the mitochondrial fusion factor mitofusin 1. J. Neurochem. 2011, 118, 636-645. [CrossRef]

30. Zhang, Q.; Wu, J.; Wu, R.; Ma, J.; Du, G.; Jiao, R.; Tian, Y.; Zheng, Z.; Yuan, Z. DJ-1 promotes the proteasomal degradation of Fis1: Implications of DJ-1 in neuronal protection. Biochem. J. 2012, 447, 261-269. [CrossRef] [PubMed] 
31. Costello, J.L.; Castro, I.G.; Camoes, F.; Schrader, T.A.; McNeall, D.; Yang, J.; Giannopoulou, E.A.; Gomes, S.; Pogenberg, V.; Bonekamp, N.A.; et al. Predicting the targeting of tail-anchored proteins to subcellular compartments in mammalian cells. J. Cell Sci. 2017, 130, 1675-1687. [CrossRef] [PubMed]

32. Gandre-Babbe, S.; van der Bliek, A.M. The novel tail-anchored membrane protein Mff controls mitochondrial and peroxisomal fission in mammalian cells. Mol. Biol. Cell 2008, 19, 2402-2412. [CrossRef] [PubMed]

33. Osellame, L.D.; Singh, A.P.; Stroud, D.A.; Palmer, C.S.; Stojanovski, D.; Ramachandran, R.; Ryan, M.T. Cooperative and independent roles of the Drp1 adaptors Mff, MiD49 and MiD51 in mitochondrial fission. J. Cell Sci. 2016, 129, $2170-2181$. [CrossRef] [PubMed]

34. Koirala, S.; Guo, Q.; Kalia, R.; Bui, H.T.; Eckert, D.M.; Frost, A.; Shaw, J.M. Interchangeable adaptors regulate mitochondrial dynamin assembly for membrane scission. Proc. Natl. Acad. Sci. USA 2013, 110, E1342-E1351. [CrossRef] [PubMed]

35. Otera, H.; Wang, C.; Cleland, M.M.; Setoguchi, K.; Yokota, S.; Youle, R.J.; Mihara, K. Mff is an essential factor for mitochondrial recruitment of Drp1 during mitochondrial fission in mammalian cells. J. Cell Biol. 2010, 191, 1141-1158. [CrossRef]

36. Loson, O.C.; Meng, S.; Ngo, H.; Liu, R.; Kaiser, J.T.; Chan, D.C. Crystal structure and functional analysis of MiD49, a receptor for the mitochondrial fission protein Drp1. Protein Sci. 2015, 24, 386-394. [CrossRef] [PubMed]

37. Zhang, Z.; Liu, L.; Wu, S.; Xing, D. Drp1, Mff, Fis1, and MiD51 are coordinated to mediate mitochondrial fission during UV irradiation-induced apoptosis. FASEB J. 2016, 30, 466-476. [CrossRef]

38. Taguchi, N.; Ishihara, N.; Jofuku, A.; Oka, T.; Mihara, K. Mitotic phosphorylation of dynamin-related GTPase Drp1 participates in mitochondrial fission. J. Biol. Chem. 2007, 282, 11521-11529. [CrossRef]

39. Owens, K.; Park, J.H.; Gourley, S.; Jones, H.; Kristian, T. Mitochondrial dynamics: Cell-type and hippocampal region specific changes following global cerebral ischemia. J. Bioenerg. Biomembr. 2015, 47, 13-31. [CrossRef]

40. Westermann, B. Bioenergetic role of mitochondrial fusion and fission. Biochim. Biophys. Acta 2012, 1817, 1833-1838. [CrossRef]

41. Sedlackova, L.; Korolchuk, V.I. Mitochondrial quality control as a key determinant of cell survival. Biochim. Biophys. Acta Mol. Cell Res. 2019, 1866, 575-587. [CrossRef] [PubMed]

42. Yang, L.; Long, Q.; Liu, J.; Tang, H.; Li, Y.; Bao, F.; Qin, D.; Pei, D.; Liu, X. Mitochondrial fusion provides an 'initial metabolic complementation' controlled by mtDNA. Cell. Mol. Life Sci. 2015, 72, 2585-2598. [CrossRef] [PubMed]

43. Van der Bliek, A.M.; Shen, Q.; Kawajiri, S. Mechanisms of mitochondrial fission and fusion. Cold Spring Harb. Perspect. Biol. 2013, 5, a011072. [CrossRef]

44. Koshiba, T.; Detmer, S.A.; Kaiser, J.T.; Chen, H.; McCaffery, J.M.; Chan, D.C. Structural basis of mitochondrial tethering by mitofusin complexes. Science 2004, 305, 858-862. [CrossRef]

45. Chen, H.; Detmer, S.A.; Ewald, A.J.; Griffin, E.E.; Fraser, S.E.; Chan, D.C. Mitofusins Mfn1 and Mfn2 coordinately regulate mitochondrial fusion and are essential for embryonic development. J. Cell Biol. 2003, 160, 189-200. [CrossRef] [PubMed]

46. Misko, A.; Jiang, S.; Wegorzewska, I.; Milbrandt, J.; Baloh, R.H. Mitofusin 2 is necessary for transport of axonal mitochondria and interacts with the Miro/Milton complex. J. Neurosci. 2010, 30, 4232-4240. [CrossRef]

47. Filadi, R.; Greotti, E.; Pizzo, P. Highlighting the endoplasmic reticulum-mitochondria connection: Focus on Mitofusin 2. Pharmacol. Res. 2018, 128, 42-51. [CrossRef] [PubMed]

48. De Brito, O.M.; Scorrano, L. Mitofusin 2 tethers endoplasmic reticulum to mitochondria. Nature 2008, 456, 605-610. [CrossRef]

49. Kimura, M.; Okano, Y. Human Misato regulates mitochondrial distribution and morphology. Exp. Cell Res. 2007, 313, 1393-1404. [CrossRef]

50. Nasca, A.; Scotton, C.; Zaharieva, I.; Neri, M.; Selvatici, R.; Magnusson, O.T.; Gal, A.; Weaver, D.; Rossi, R.; Armaroli, A.; et al. Recessive mutations in MSTO1 cause mitochondrial dynamics impairment, leading to myopathy and ataxia. Hum. Mutat. 2017, 38, 970-977. [CrossRef]

51. Gal, A.; Balicza, P.; Weaver, D.; Naghdi, S.; Joseph, S.K.; Varnai, P.; Gyuris, T.; Horvath, A.; Nagy, L.; Seifert, E.L.; et al. MSTO1 is a cytoplasmic pro-mitochondrial fusion protein, whose mutation induces myopathy and ataxia in humans. EMBO Mol. Med. 2017, 9, 967-984. [CrossRef] [PubMed]

52. Ishihara, N.; Fujita, Y.; Oka, T.; Mihara, K. Regulation of mitochondrial morphology through proteolytic cleavage of OPA1. EMBO J. 2006, 25, 2966-2977. [CrossRef] [PubMed]

53. Mishra, P.; Carelli, V.; Manfredi, G.; Chan, D.C. Proteolytic cleavage of Opa1 stimulates mitochondrial inner membrane fusion and couples fusion to oxidative phosphorylation. Cell Metab. 2014, 19, 630-641. [CrossRef] [PubMed]

54. Satoh, M.; Hamamoto, T.; Seo, N.; Kagawa, Y.; Endo, H. Differential sublocalization of the dynamin-related protein OPA1 isoforms in mitochondria. Biochem. Biophys. Res. Commun. 2003, 300, 482-493. [CrossRef]

55. MacVicar, T.; Langer, T. OPA1 processing in cell death and disease-The long and short of it. J. Cell Sci. 2016, 129, 2297-2306. [CrossRef]

56. Cipolat, S.; Rudka, T.; Hartmann, D.; Costa, V.; Serneels, L.; Craessaerts, K.; Metzger, K.; Frezza, C.; Annaert, W.; D’Adamio, L.; et al. Mitochondrial rhomboid PARL regulates cytochrome $\mathrm{c}$ release during apoptosis via OPA1-dependent cristae remodeling. Cell 2006, 126, 163-175. [CrossRef] [PubMed]

57. Song, Z.; Ghochani, M.; McCaffery, J.M.; Frey, T.G.; Chan, D.C. Mitofusins and OPA1 mediate sequential steps in mitochondrial membrane fusion. Mol. Biol. Cell 2009, 20, 3525-3532. [CrossRef] [PubMed] 
58. Stiburek, L.; Cesnekova, J.; Kostkova, O.; Fornuskova, D.; Vinsova, K.; Wenchich, L.; Houstek, J.; Zeman, J. YME1L controls the accumulation of respiratory chain subunits and is required for apoptotic resistance, cristae morphogenesis, and cell proliferation. Mol. Biol. Cell 2012, 23, 1010-1023. [CrossRef]

59. Anand, R.; Wai, T.; Baker, M.J.; Kladt, N.; Schauss, A.C.; Rugarli, E.; Langer, T. The i-AAA protease YME1L and OMA1 cleave OPA1 to balance mitochondrial fusion and fission. J. Cell Biol. 2014, 204, 919-929. [CrossRef]

60. Head, B.; Griparic, L.; Amiri, M.; Gandre-Babbe, S.; van der Bliek, A.M. Inducible proteolytic inactivation of OPA1 mediated by the OMA1 protease in mammalian cells. J. Cell Biol. 2009, 187, 959-966. [CrossRef]

61. Ehses, S.; Raschke, I.; Mancuso, G.; Bernacchia, A.; Geimer, S.; Tondera, D.; Martinou, J.C.; Westermann, B.; Rugarli, E.I.; Langer, T. Regulation of OPA1 processing and mitochondrial fusion by m-AAA protease isoenzymes and OMA1. J. Cell Biol. 2009, 187, 1023-1036. [CrossRef] [PubMed]

62. Baker, M.J.; Lampe, P.A.; Stojanovski, D.; Korwitz, A.; Anand, R.; Tatsuta, T.; Langer, T. Stress-induced OMA1 activation and autocatalytic turnover regulate OPA1-dependent mitochondrial dynamics. EMBO J. 2014, 33, 578-593. [CrossRef] [PubMed]

63. Zhang, K.; Li, H.; Song, Z. Membrane depolarization activates the mitochondrial protease OMA1 by stimulating self-cleavage. EMBO Rep. 2014, 15, 576-585. [CrossRef]

64. Song, Z.; Chen, H.; Fiket, M.; Alexander, C.; Chan, D.C. OPA1 processing controls mitochondrial fusion and is regulated by mRNA splicing, membrane potential, and Yme1L. J. Cell Biol. 2007, 178, 749-755. [CrossRef] [PubMed]

65. Duvezin-Caubet, S.; Jagasia, R.; Wagener, J.; Hofmann, S.; Trifunovic, A.; Hansson, A.; Chomyn, A.; Bauer, M.F.; Attardi, G.; Larsson, N.G.; et al. Proteolytic processing of OPA1 links mitochondrial dysfunction to alterations in mitochondrial morphology. J. Biol. Chem. 2006, 281, 37972-37979. [CrossRef]

66. Kumar, R.; Bukowski, M.J.; Wider, J.M.; Reynolds, C.A.; Calo, L.; Lepore, B.; Tousignant, R.; Jones, M.; Przyklenk, K.; Sanderson, T.H. Mitochondrial dynamics following global cerebral ischemia. Mol. Cell. Neurosci. 2016, 76, 68-75. [CrossRef] [PubMed]

67. Baburamani, A.A.; Hurling, C.; Stolp, H.; Sobotka, K.; Gressens, P.; Hagberg, H.; Thornton, C. Mitochondrial Optic Atrophy (OPA) 1 Processing Is Altered in Response to Neonatal Hypoxic-Ischemic Brain Injury. Int. J. Mol. Sci. 2015, 16, 22509-22526. [CrossRef]

68. Jahani-Asl, A.; Pilon-Larose, K.; Xu, W.; MacLaurin, J.G.; Park, D.S.; McBride, H.M.; Slack, R.S. The mitochondrial inner membrane GTPase, optic atrophy 1 (Opa1), restores mitochondrial morphology and promotes neuronal survival following excitotoxicity. J. Biol. Chem. 2011, 286, 4772-4782. [CrossRef]

69. Griparic, L.; Kanazawa, T.; van der Bliek, A.M. Regulation of the mitochondrial dynamin-like protein Opa1 by proteolytic cleavage. J. Cell Biol. 2007, 178, 757-764. [CrossRef]

70. Baricault, L.; Segui, B.; Guegand, L.; Olichon, A.; Valette, A.; Larminat, F.; Lenaers, G. OPA1 cleavage depends on decreased mitochondrial ATP level and bivalent metals. Exp. Cell Res. 2007, 313, 3800-3808. [CrossRef] [PubMed]

71. Chang, C.R.; Blackstone, C. Dynamic regulation of mitochondrial fission through modification of the dynamin-related protein Drp1. Ann. N. Y. Acad. Sci. 2010, 1201, 34-39. [CrossRef] [PubMed]

72. Xu, S.; Cherok, E.; Das, S.; Li, S.; Roelofs, B.A.; Ge, S.X.; Polster, B.M.; Boyman, L.; Lederer, W.J.; Wang, C.; et al. Mitochondrial E3 ubiquitin ligase MARCH5 controls mitochondrial fission and cell sensitivity to stress-induced apoptosis through regulation of MiD49 protein. Mol. Biol. Cell 2016, 27, 349-359. [CrossRef] [PubMed]

73. Toyama, E.Q.; Herzig, S.; Courchet, J.; Lewis, T.L., Jr.; Loson, O.C.; Hellberg, K.; Young, N.P.; Chen, H.; Polleux, F.; Chan, D.C.; et al. Metabolism. AMP-activated protein kinase mediates mitochondrial fission in response to energy stress. Science 2016, 351, 275-281. [CrossRef] [PubMed]

74. Allfrey, V.G.; Faulkner, R.; Mirsky, A.E. Acetylation and Methylation of Histones and Their Possible Role in the Regulation of Rna Synthesis. Proc. Natl. Acad. Sci. USA 1964, 51, 786-794. [CrossRef]

75. Norvell, A.; McMahon, S.B. Cell biology. Rise of the rival. Science 2010, 327, 964-965. [CrossRef] [PubMed]

76. Saha, R.N.; Pahan, K. HATs and HDACs in neurodegeneration: A tale of disconcerted acetylation homeostasis. Cell Death Differ. 2006, 13, 539-550. [CrossRef] [PubMed]

77. Yoon, S.; Eom, G.H. HDAC and HDAC Inhibitor: From Cancer to Cardiovascular Diseases. Chonnam Med. J. 2016, 52, 1-11. [CrossRef] [PubMed]

78. Borra, M.T.; Langer, M.R.; Slama, J.T.; Denu, J.M. Substrate specificity and kinetic mechanism of the Sir2 family of NAD+dependent histone/protein deacetylases. Biochemistry 2004, 43, 9877-9887. [CrossRef] [PubMed]

79. Michishita, E.; Park, J.Y.; Burneskis, J.M.; Barrett, J.C.; Horikawa, I. Evolutionarily conserved and nonconserved cellular localizations and functions of human SIRT proteins. Mol. Biol. Cell 2005, 16, 4623-4635. [CrossRef]

80. Jing, E.; Gesta, S.; Kahn, C.R. SIRT2 regulates adipocyte differentiation through FoxO1 acetylation/deacetylation. Cell Metab. 2007, 6, 105-114. [CrossRef] [PubMed]

81. Hirschey, M.D.; Shimazu, T.; Huang, J.Y.; Schwer, B.; Verdin, E. SIRT3 regulates mitochondrial protein acetylation and intermediary metabolism. Cold Spring Harb. Quant. Biol. 2011, 76, 267-277. [CrossRef]

82. Lombard, D.B.; Alt, F.W.; Cheng, H.L.; Bunkenborg, J.; Streeper, R.S.; Mostoslavsky, R.; Kim, J.; Yancopoulos, G.; Valenzuela, D.; Murphy, A.; et al. Mammalian Sir2 homolog SIRT3 regulates global mitochondrial lysine acetylation. Mol. Cell. Biol. 2007, 27, 8807-8814. [CrossRef] 
83. Haigis, M.C.; Mostoslavsky, R.; Haigis, K.M.; Fahie, K.; Christodoulou, D.C.; Murphy, A.J.; Valenzuela, D.M.; Yancopoulos, G.D.; Karow, M.; Blander, G.; et al. SIRT4 inhibits glutamate dehydrogenase and opposes the effects of calorie restriction in pancreatic beta cells. Cell 2006, 126, 941-954. [CrossRef]

84. Rardin, M.J.; He, W.; Nishida, Y.; Newman, J.C.; Carrico, C.; Danielson, S.R.; Guo, A.; Gut, P.; Sahu, A.K.; Li, B.; et al. SIRT5 regulates the mitochondrial lysine succinylome and metabolic networks. Cell Metab. 2013, 18, 920-933. [CrossRef]

85. Ahuja, N.; Schwer, B.; Carobbio, S.; Waltregny, D.; North, B.J.; Castronovo, V.; Maechler, P.; Verdin, E. Regulation of insulin secretion by SIRT4, a mitochondrial ADP-ribosyltransferase. J. Biol. Chem. 2007, 282, 33583-33592. [CrossRef] [PubMed]

86. Rardin, M.J.; Newman, J.C.; Held, J.M.; Cusack, M.P.; Sorensen, D.J.; Li, B.; Schilling, B.; Mooney, S.D.; Kahn, C.R.; Verdin, E.; et al. Label-free quantitative proteomics of the lysine acetylome in mitochondria identifies substrates of SIRT3 in metabolic pathways. Proc. Natl. Acad. Sci. USA 2013, 110, 6601-6606. [CrossRef]

87. Park, J.; Chen, Y.; Tishkoff, D.X.; Peng, C.; Tan, M.; Dai, L.; Xie, Z.; Zhang, Y.; Zwaans, B.M.; Skinner, M.E.; et al. SIRT5-mediated lysine desuccinylation impacts diverse metabolic pathways. Mol. Cell 2013, 50, 919-930. [CrossRef] [PubMed]

88. Tanno, M.; Sakamoto, J.; Miura, T.; Shimamoto, K.; Horio, Y. Nucleocytoplasmic shuttling of the NAD+-dependent histone deacetylase SIRT1. J. Biol. Chem. 2007, 282, 6823-6832. [CrossRef]

89. North, B.J.; Marshall, B.L.; Borra, M.T.; Denu, J.M.; Verdin, E. The human Sir2 ortholog, SIRT2, is an NAD+-dependent tubulin deacetylase. Mol. Cell 2003, 11, 437-444. [CrossRef]

90. Ahn, B.H.; Kim, H.S.; Song, S.; Lee, I.H.; Liu, J.; Vassilopoulos, A.; Deng, C.X.; Finkel, T. A role for the mitochondrial deacetylase Sirt3 in regulating energy homeostasis. Proc. Natl. Acad. Sci. USA 2008, 105, 14447-14452. [CrossRef]

91. Du, J.; Zhou, Y.; Su, X.; Yu, J.J.; Khan, S.; Jiang, H.; Kim, J.; Woo, J.; Kim, J.H.; Choi, B.H.; et al. Sirt5 is a NAD-dependent protein lysine demalonylase and desuccinylase. Science 2011, 334, 806-809. [CrossRef]

92. Liszt, G.; Ford, E.; Kurtev, M.; Guarente, L. Mouse Sir2 homolog SIRT6 is a nuclear ADP-ribosyltransferase. J. Biol. Chem. 2005, 280, 21313-21320. [CrossRef] [PubMed]

93. Ford, E.; Voit, R.; Liszt, G.; Magin, C.; Grummt, I.; Guarente, L. Mammalian Sir2 homolog SIRT7 is an activator of RNA polymerase I transcription. Genes Dev. 2006, 20, 1075-1080. [CrossRef]

94. Marmorstein, R.; Trievel, R.C. Histone modifying enzymes: Structures, mechanisms, and specificities. Biochim. Biophys. Acta 2009, 1789, 58-68. [CrossRef] [PubMed]

95. Roth, S.Y.; Denu, J.M.; Allis, C.D. Histone acetyltransferases. Annu. Rev. Biochem. 2001, 70, 81-120. [CrossRef] [PubMed]

96. Scott, I.; Webster, B.R.; Li, J.H.; Sack, M.N. Identification of a molecular component of the mitochondrial acetyltransferase programme: A novel role for GCN5L1. Biochem. J. 2012, 443, 655-661. [CrossRef]

97. Hu, Q.; Zhang, H.; Gutierrez Cortes, N.; Wu, D.; Wang, P.; Zhang, J.; Mattison, J.A.; Smith, E.; Bettcher, L.F.; Wang, M.; et al. Increased Drp1 Acetylation by Lipid Overload Induces Cardiomyocyte Death and Heart Dysfunction. Circ. Res. 2020, 126, 456-470. [CrossRef]

98. Sever, S.; Muhlberg, A.B.; Schmid, S.L. Impairment of dynamin's GAP domain stimulates receptor-mediated endocytosis. Nature 1999, 398, 481-486. [CrossRef]

99. Wang, L.; Zhang, T.; Wang, L.; Cai, Y.; Zhong, X.; He, X.; Hu, L.; Tian, S.; Wu, M.; Hui, L.; et al. Fatty acid synthesis is critical for stem cell pluripotency via promoting mitochondrial fission. EMBO J. 2017, 36, 1330-1347. [CrossRef] [PubMed]

100. Samant, S.A.; Zhang, H.J.; Hong, Z.; Pillai, V.B.; Sundaresan, N.R.; Wolfgeher, D.; Archer, S.L.; Chan, D.C.; Gupta, M.P. SIRT3 deacetylates and activates OPA1 to regulate mitochondrial dynamics during stress. Mol. Cell. Biol. 2014, 34, 807-819. [CrossRef]

101. Lee, J.Y.; Kapur, M.; Li, M.; Choi, M.C.; Choi, S.; Kim, H.J.; Kim, I.; Lee, E.; Taylor, J.P.; Yao, T.P. MFN1 deacetylation activates adaptive mitochondrial fusion and protects metabolically challenged mitochondria. J. Cell Sci. 2014, 127, 4954-4963. [CrossRef]

102. Park, Y.Y.; Nguyen, O.T.; Kang, H.; Cho, H. MARCH5-mediated quality control on acetylated Mfn1 facilitates mitochondrial homeostasis and cell survival. Cell Death Dis. 2014, 5, e1172. [CrossRef] [PubMed]

103. Nakamura, T.; Lipton, S.A. Protein S-Nitrosylation as a Therapeutic Target for Neurodegenerative Diseases. Trends Pharmacol. Sci. 2016, 37, 73-84. [CrossRef] [PubMed]

104. Cadenas, E.; Davies, K.J. Mitochondrial free radical generation, oxidative stress, and aging. Free Radic. Biol. Med. 2000, 29, 222-230. [CrossRef]

105. Galkin, A. Brain Ischemia/Reperfusion Injury and Mitochondrial Complex I Damage. Biochemistry 2019, 84, 1411-1423. [CrossRef]

106. Droge, W. Free radicals in the physiological control of cell function. Physiol. Rev. 2002, 82, 47-95. [CrossRef]

107. Kowaltowski, A.J.; de Souza-Pinto, N.C.; Castilho, R.F.; Vercesi, A.E. Mitochondria and reactive oxygen species. Free Radic. Biol. Med. 2009, 47, 333-343. [CrossRef] [PubMed]

108. Andreyev, A.Y.; Kushnareva, Y.E.; Starkov, A.A. Mitochondrial metabolism of reactive oxygen species. Biochemistry 2005, 70, 200-214. [CrossRef] [PubMed]

109. Lin, M.T.; Beal, M.F. Mitochondrial dysfunction and oxidative stress in neurodegenerative diseases. Nature 2006, 443, 787-795. [CrossRef]

110. Inarrea, P.; Moini, H.; Han, D.; Rettori, D.; Aguilo, I.; Alava, M.A.; Iturralde, M.; Cadenas, E. Mitochondrial respiratory chain and thioredoxin reductase regulate intermembrane $\mathrm{Cu}, \mathrm{Zn}$-superoxide dismutase activity: Implications for mitochondrial energy metabolism and apoptosis. Biochem. J. 2007, 405, 173-179. [CrossRef] [PubMed]

111. Stowe, D.F.; Camara, A.K. Mitochondrial reactive oxygen species production in excitable cells: Modulators of mitochondrial and cell function. Antioxid. Redox Signal. 2009, 11, 1373-1414. [CrossRef] [PubMed] 
112. Cheng, A.; Yang, Y.; Zhou, Y.; Maharana, C.; Lu, D.; Peng, W.; Liu, Y.; Wan, R.; Marosi, K.; Misiak, M.; et al. Mitochondrial SIRT3 Mediates Adaptive Responses of Neurons to Exercise and Metabolic and Excitatory Challenges. Cell Metab. 2016, $23,128-142$. [CrossRef] [PubMed]

113. Klimova, N.; Long, A.; Kristian, T. Nicotinamide mononucleotide alters mitochondrial dynamics by SIRT3 dependent mechanism in male mice. J. Neurosci. Res. 2019, 97, 975-990. [CrossRef] [PubMed]

114. Qiu, X.; Brown, K.; Hirschey, M.D.; Verdin, E.; Chen, D. Calorie restriction reduces oxidative stress by SIRT3-mediated SOD2 activation. Cell Metab. 2010, 12, 662-667. [CrossRef] [PubMed]

115. Liu, X.; Zhang, L.; Wang, P.; Li, X.; Qiu, D.; Li, L.; Zhang, J.; Hou, X.; Han, L.; Ge, J.; et al. Sirt3-dependent deacetylation of SOD2 plays a protective role against oxidative stress in oocytes from diabetic mice. Cell Cycle 2017, 16, 1302-1308. [CrossRef]

116. Klimova, N.; Fearnow, A.; Long, A.; Kristian, T. NAD(+) precursor modulates post-ischemic mitochondrial fragmentation and reactive oxygen species generation via SIRT3 dependent mechanisms. Exp. Neurol. 2020, 325, 113144. [CrossRef] [PubMed]

117. Kim, S.H.; Lu, H.F.; Alano, C.C. Neuronal Sirt3 protects against excitotoxic injury in mouse cortical neuron culture. PLoS ONE 2011, 6, e14731. [CrossRef] [PubMed]

118. Sheng, Z.H.; Cai, Q. Mitochondrial transport in neurons: Impact on synaptic homeostasis and neurodegeneration. Nat. Rev. Neurosci. 2012, 13, 77-93. [CrossRef] [PubMed]

119. Hollenbeck, P.J.; Saxton, W.M. The axonal transport of mitochondria. J. Cell Sci. 2005, 118, 5411-5419. [CrossRef] [PubMed]

120. Morris, R.L.; Hollenbeck, P.J. Axonal transport of mitochondria along microtubules and F-actin in living vertebrate neurons. J. Cell Biol. 1995, 131, 1315-1326. [CrossRef] [PubMed]

121. Anesti, V.; Scorrano, L. The relationship between mitochondrial shape and function and the cytoskeleton. Biochim. Biophys. Acta 2006, 1757, 692-699. [CrossRef]

122. Bartolak-Suki, E.; Imsirovic, J.; Nishibori, Y.; Krishnan, R.; Suki, B. Regulation of Mitochondrial Structure and Dynamics by the Cytoskeleton and Mechanical Factors. Int. J. Mol. Sci. 2017, 18, 1812. [CrossRef]

123. Ligon, L.A.; Steward, O. Role of microtubules and actin filaments in the movement of mitochondria in the axons and dendrites of cultured hippocampal neurons. J. Comp. Neurol. 2000, 427, 351-361. [CrossRef]

124. Moritz, M.; Agard, D.A. Gamma-tubulin complexes and microtubule nucleation. Curr. Opin. Struct. Biol. 2001, 11, $174-181$. [CrossRef]

125. Hammond, J.W.; Cai, D.; Verhey, K.J. Tubulin modifications and their cellular functions. Curr. Opin. Cell Biol. 2008, 20, 71-76. [CrossRef]

126. Janke, C.; Kneussel, M. Tubulin post-translational modifications: Encoding functions on the neuronal microtubule cytoskeleton. Trends Neurosci. 2010, 33, 362-372. [CrossRef] [PubMed]

127. Nogales, E. Structural insights into microtubule function. Annu. Rev. Biochem. 2000, 69, 277-302. [CrossRef]

128. Cai, Q.; Davis, M.L.; Sheng, Z.H. Regulation of axonal mitochondrial transport and its impact on synaptic transmission. Neurosci. Res. 2011, 70, 9-15. [CrossRef]

129. Paturle, L.; Wehland, J.; Margolis, R.L.; Job, D. Complete separation of tyrosinated, detyrosinated, and nontyrosinatable brain tubulin subpopulations using affinity chromatography. Biochemistry 1989, 28, 2698-2704. [CrossRef]

130. Paturle-Lafanechere, L.; Manier, M.; Trigault, N.; Pirollet, F.; Mazarguil, H.; Job, D. Accumulation of delta 2-tubulin, a major tubulin variant that cannot be tyrosinated, in neuronal tissues and in stable microtubule assemblies. J. Cell Sci. 1994, 107 Pt 6, 1529-1543. [CrossRef]

131. Suryavanshi, S.; Edde, B.; Fox, L.A.; Guerrero, S.; Hard, R.; Hennessey, T.; Kabi, A.; Malison, D.; Pennock, D.; Sale, W.S.; et al. Tubulin glutamylation regulates ciliary motility by altering inner dynein arm activity. Curr. Biol. 2010, 20, 435-440. [CrossRef] [PubMed]

132. Kubo, T.; Yanagisawa, H.A.; Yagi, T.; Hirono, M.; Kamiya, R. Tubulin polyglutamylation regulates axonemal motility by modulating activities of inner-arm dyneins. Curr. Biol. 2010, 20, 441-445. [CrossRef] [PubMed]

133. Friedman, J.R.; Lackner, L.L.; West, M.; DiBenedetto, J.R.; Nunnari, J.; Voeltz, G.K. ER tubules mark sites of mitochondrial division. Science 2011, 334, 358-362. [CrossRef] [PubMed]

134. Korobova, F.; Ramabhadran, V.; Higgs, H.N. An actin-dependent step in mitochondrial fission mediated by the ER-associated formin INF2. Science 2013, 339, 464-467. [CrossRef]

135. Manor, U.; Bartholomew, S.; Golani, G.; Christenson, E.; Kozlov, M.; Higgs, H.; Spudich, J.; Lippincott-Schwartz, J. A mitochondriaanchored isoform of the actin-nucleating spire protein regulates mitochondrial division. Elife 2015, 4, e08828. [CrossRef]

136. Chakrabarti, R.; Ji, W.K.; Stan, R.V.; de Juan Sanz, J.; Ryan, T.A.; Higgs, H.N. INF2-mediated actin polymerization at the ER stimulates mitochondrial calcium uptake, inner membrane constriction, and division. J. Cell Biol. 2018, 217, 251-268. [CrossRef] [PubMed]

137. Rehklau, K.; Hoffmann, L.; Gurniak, C.B.; Ott, M.; Witke, W.; Scorrano, L.; Culmsee, C.; Rust, M.B. Cofilin1-dependent actin dynamics control DRP1-mediated mitochondrial fission. Cell Death Dis. 2017, 8, e3063. [CrossRef]

138. Varland, S.; Vandekerckhove, J.; Drazic, A. Actin Post-translational Modifications: The Cinderella of Cytoskeletal Control. Trends Biochem. Sci. 2019, 44, 502-516. [CrossRef]

139. Mu, A.; Fung, T.S.; Kettenbach, A.N.; Chakrabarti, R.; Higgs, H.N. A complex containing lysine-acetylated actin inhibits the formin INF2. Nat. Cell Biol. 2019, 21, 592-602. [CrossRef] 
140. Reed, N.A.; Cai, D.; Blasius, T.L.; Jih, G.T.; Meyhofer, E.; Gaertig, J.; Verhey, K.J. Microtubule acetylation promotes kinesin-1 binding and transport. Curr. Biol. 2006, 16, 2166-2172. [CrossRef]

141. Dompierre, J.P.; Godin, J.D.; Charrin, B.C.; Cordelieres, F.P.; King, S.J.; Humbert, S.; Saudou, F. Histone deacetylase 6 inhibition compensates for the transport deficit in Huntington's disease by increasing tubulin acetylation. J. Neurosci. 2007, 27, 3571-3583. [CrossRef]

142. Nogales, E.; Wolf, S.G.; Downing, K.H. Structure of the alpha beta tubulin dimer by electron crystallography. Nature 1998, 391, 199-203. [CrossRef]

143. Cueva, J.G.; Hsin, J.; Huang, K.C.; Goodman, M.B. Posttranslational acetylation of alpha-tubulin constrains protofilament number in native microtubules. Curr. Biol. 2012, 22, 1066-1074. [CrossRef]

144. Topalidou, I.; Keller, C.; Kalebic, N.; Nguyen, K.C.; Somhegyi, H.; Politi, K.A.; Heppenstall, P.; Hall, D.H.; Chalfie, M. Genetically separable functions of the MEC-17 tubulin acetyltransferase affect microtubule organization. Curr. Biol. 2012, 22, 1057-1065. [CrossRef] [PubMed]

145. Hammond, J.W.; Huang, C.F.; Kaech, S.; Jacobson, C.; Banker, G.; Verhey, K.J. Posttranslational modifications of tubulin and the polarized transport of kinesin-1 in neurons. Mol. Biol. Cell 2010, 21, 572-583. [CrossRef]

146. Perdiz, D.; Mackeh, R.; Pous, C.; Baillet, A. The ins and outs of tubulin acetylation: More than just a post-translational modification? Cell Signal. 2011, 23, 763-771. [CrossRef]

147. Akella, J.S.; Wloga, D.; Kim, J.; Starostina, N.G.; Lyons-Abbott, S.; Morrissette, N.S.; Dougan, S.T.; Kipreos, E.T.; Gaertig, J. MEC-17 is an alpha-tubulin acetyltransferase. Nature 2010, 467, 218-222. [CrossRef]

148. Shida, T.; Cueva, J.G.; Xu, Z.; Goodman, M.B.; Nachury, M.V. The major alpha-tubulin K40 acetyltransferase alphaTAT1 promotes rapid ciliogenesis and efficient mechanosensation. Proc. Natl. Acad. Sci. USA 2010, 107, 21517-21522. [CrossRef] [PubMed]

149. Kim, G.W.; Li, L.; Ghorbani, M.; You, L.; Yang, X.J. Mice lacking alpha-tubulin acetyltransferase 1 are viable but display alpha-tubulin acetylation deficiency and dentate gyrus distortion. J. Biol. Chem. 2013, 288, 20334-20350. [CrossRef]

150. Mackeh, R.; Lorin, S.; Ratier, A.; Mejdoubi-Charef, N.; Baillet, A.; Bruneel, A.; Hamai, A.; Codogno, P.; Pous, C.; Perdiz, D. Reactive oxygen species, AMP-activated protein kinase, and the transcription cofactor p300 regulate alpha-tubulin acetyltransferase-1 (alphaTAT-1/MEC-17)-dependent microtubule hyperacetylation during cell stress. J. Biol. Chem. 2014, 289, 11816-11828. [CrossRef]

151. Nahhas, F.; Dryden, S.C.; Abrams, J.; Tainsky, M.A. Mutations in SIRT2 deacetylase which regulate enzymatic activity but not its interaction with HDAC6 and tubulin. Mol. Cell. Biochem. 2007, 303, 221-230. [CrossRef]

152. Maxwell, M.M.; Tomkinson, E.M.; Nobles, J.; Wizeman, J.W.; Amore, A.M.; Quinti, L.; Chopra, V.; Hersch, S.M.; Kazantsev, A.G. The Sirtuin 2 microtubule deacetylase is an abundant neuronal protein that accumulates in the aging CNS. Hum. Mol. Genet. 2011, 20, 3986-3996. [CrossRef]

153. Zhang, Y.; Kwon, S.; Yamaguchi, T.; Cubizolles, F.; Rousseaux, S.; Kneissel, M.; Cao, C.; Li, N.; Cheng, H.L.; Chua, K.; et al. Mice lacking histone deacetylase 6 have hyperacetylated tubulin but are viable and develop normally. Mol. Cell Biol. 2008, 28, 1688-1701. [CrossRef]

154. Govindarajan, N.; Rao, P.; Burkhardt, S.; Sananbenesi, F.; Schluter, O.M.; Bradke, F.; Lu, J.; Fischer, A. Reducing HDAC6 ameliorates cognitive deficits in a mouse model for Alzheimer's disease. EMBO Mol. Med. 2013, 5, 52-63. [CrossRef]

155. Southwood, C.M.; Peppi, M.; Dryden, S.; Tainsky, M.A.; Gow, A. Microtubule deacetylases, SirT2 and HDAC6, in the nervous system. Neurochem. Res. 2007, 32, 187-195. [CrossRef]

156. Fukada, M.; Hanai, A.; Nakayama, A.; Suzuki, T.; Miyata, N.; Rodriguiz, R.M.; Wetsel, W.C.; Yao, T.P.; Kawaguchi, Y. Loss of deacetylation activity of Hdac6 affects emotional behavior in mice. PLoS ONE 2012, 7, e30924. [CrossRef]

157. Chen, S.; Owens, G.C.; Makarenkova, H.; Edelman, D.B. HDAC6 regulates mitochondrial transport in hippocampal neurons. PLoS ONE 2010, 5, e10848. [CrossRef]

158. Guo, W.; Naujock, M.; Fumagalli, L.; Vandoorne, T.; Baatsen, P.; Boon, R.; Ordovas, L.; Patel, A.; Welters, M.; Vanwelden, T.; et al. HDAC6 inhibition reverses axonal transport defects in motor neurons derived from FUS-ALS patients. Nat. Commun. 2017, 8, 861. [CrossRef]

159. Kamemura, K.; Ogawa, M.; Ohkubo, S.; Ohtsuka, Y.; Shitara, Y.; Komiya, T.; Maeda, S.; Ito, A.; Yoshida, M. Depression of mitochondrial metabolism by downregulation of cytoplasmic deacetylase, HDAC6. FEBS Lett. 2012, 586, 1379-1383. [CrossRef]

160. Kim, C.; Choi, H.; Jung, E.S.; Lee, W.; Oh, S.; Jeon, N.L.; Mook-Jung, I. HDAC6 inhibitor blocks amyloid beta-induced impairment of mitochondrial transport in hippocampal neurons. PLoS ONE 2012, 7, e42983. [CrossRef]

161. Wong, Y.C.; Ysselstein, D.; Krainc, D. Mitochondria-lysosome contacts regulate mitochondrial fission via RAB7 GTP hydrolysis. Nature 2018, 554, 382-386. [CrossRef]

162. Nagashima, S.; Tabara, L.C.; Tilokani, L.; Paupe, V.; Anand, H.; Pogson, J.H.; Zunino, R.; McBride, H.M.; Prudent, J. Golgi-derived PI(4)P-containing vesicles drive late steps of mitochondrial division. Science 2020, 367, 1366-1371. [CrossRef]

163. Tabara, L.C.; Morris, J.L.; Prudent, J. The Complex Dance of Organelles during Mitochondrial Division. Trends Cell Biol. 2021, 31, 241-253. [CrossRef]

164. Biel, T.G.; Lee, S.; Flores-Toro, J.A.; Dean, J.W.; Go, K.L.; Lee, M.H.; Law, B.K.; Law, M.E.; Dunn, W.A., Jr.; Zendejas, I.; et al. Sirtuin 1 suppresses mitochondrial dysfunction of ischemic mouse livers in a mitofusin 2-dependent manner. Cell Death Differ. 2016, 23, 279-290. [CrossRef] 
165. Guedes-Dias, P.; Oliveira, J.M. Lysine deacetylases and mitochondrial dynamics in neurodegeneration. Biochim. Biophys. Acta 2013, 1832, 1345-1359. [CrossRef]

166. Nakamura, T.; Cho, D.H.; Lipton, S.A. Redox regulation of protein misfolding, mitochondrial dysfunction, synaptic damage, and cell death in neurodegenerative diseases. Exp. Neurol. 2012, 238, 12-21. [CrossRef]

167. Motori, E.; Puyal, J.; Toni, N.; Ghanem, A.; Angeloni, C.; Malaguti, M.; Cantelli-Forti, G.; Berninger, B.; Conzelmann, K.K.; Gotz, M.; et al. Inflammation-induced alteration of astrocyte mitochondrial dynamics requires autophagy for mitochondrial network maintenance. Cell Metab. 2013, 18, 844-859. [CrossRef]

168. Anzell, A.R.; Fogo, G.M.; Gurm, Z.; Raghunayakula, S.; Wider, J.M.; Maheras, K.J.; Emaus, K.J.; Bryson, T.D.; Wang, M.; Neumar, R.W.; et al. Mitochondrial fission and mitophagy are independent mechanisms regulating ischemia/reperfusion injury in primary neurons. Cell Death Dis. 2021, 12, 475. [CrossRef]

169. Kumari, S.; Anderson, L.; Farmer, S.; Mehta, S.L.; Li, P.A. Hyperglycemia alters mitochondrial fission and fusion proteins in mice subjected to cerebral ischemia and reperfusion. Transl. Stroke Res. 2012, 3, 296-304. [CrossRef]

170. Liu, W.; Tian, F.; Kurata, T.; Morimoto, N.; Abe, K. Dynamic changes of mitochondrial fusion and fission proteins after transient cerebral ischemia in mice. J. Neurosci. Res. 2012, 90, 1183-1189. [CrossRef]

171. Zhang, L.; He, Z.; Zhang, Q.; Wu, Y.; Yang, X.; Niu, W.; Hu, Y.; Jia, J. Exercise pretreatment promotes mitochondrial dynamic protein OPA1 expression after cerebral ischemia in rats. Int. J. Mol. Sci. 2014, 15, 4453-4463. [CrossRef]

172. Barsoum, M.J.; Yuan, H.; Gerencser, A.A.; Liot, G.; Kushnareva, Y.; Graber, S.; Kovacs, I.; Lee, W.D.; Waggoner, J.; Cui, J.; et al. Nitric oxide-induced mitochondrial fission is regulated by dynamin-related GTPases in neurons. EMBO J. 2006, 25, 3900-3911. [CrossRef]

173. Park, J.H.; Long, A.; Owens, K.; Kristian, T. Nicotinamide mononucleotide inhibits post-ischemic NAD(+) degradation and dramatically ameliorates brain damage following global cerebral ischemia. Neurobiol. Dis. 2016, 95, 102-110. [CrossRef]

174. Belenky, P.; Bogan, K.L.; Brenner, C. NAD+ metabolism in health and disease. Trends Biochem. Sci. 2007, 32, 12-19. [CrossRef]

175. Klimova, N.; Fearnow, A.; Kristian, T. Role of NAD(+)-Modulated Mitochondrial Free Radical Generation in Mechanisms of Acute Brain Injury. Brain Sci. 2020, 10, 449. [CrossRef]

176. Xiong, T.Q.; Guo, C.Y.; Tan, B.H.; Gui, Y.; Li, Y.C. The temporal and spatial changes of microtubule cytoskeleton in the CA1 stratum radiatum following global transient ischemia. J. Chem. Neuroanat. 2019, 101, 101682. [CrossRef]

177. Guo, C.Y.; Xiong, T.Q.; Tan, B.H.; Gui, Y.; Ye, N.; Li, S.L.; Li, Y.C. The temporal and spatial changes of actin cytoskeleton in the hippocampal CA1 neurons following transient global ischemia. Brain Res. 2019, 1720, 146297. [CrossRef] 